\title{
Brand Image Theoretical Aspects
}

\author{
Margarita Išoraitè \\ Vilniaus kolegija-The University Applied Sciences, Lithuania \\ misoraite@gmail.com
}

\begin{abstract}
The article analyzes the image of a brand and a brand image, brand value assessment methods, brand value, and benefits. A brand is a word or phrase that identifies and separates goods belonging to one person from belonging to another person. A brand is one of the elements of marketing, advertising. High-quality brand brings significant benefits to the manufacturer or the trader. A brand name may consist of a brand name and a brand symbol. There is several brand value evaluation model analyze in the article, like capital market-oriented brand value model, Aaker's brand value model, the Interbrand Brand Assessment Methodology, which helps evaluate brand value and benefit.
\end{abstract}

Keywords: Brand, Brand Image, Brand Value, Brand Value Evaluation Methods

\section{Introduction}

Competition between brands is intensifying. More and more businesses are aware of the importance of branding. The image is both emotional and communicative perception of products and services that helps ensure the company's success. One of the most important goals of the company in order to profitably operate is to introduce its activities, the offered goods and services to the largest possible number of users, and thus to check their favor and reputation. According to Čereška (2004), advertising, acting as a company, product or service, can do miracles. Often, only because of a strong positive image can compete in a saturated market and achieve recognition of a product or service. Brand image can be perceived as emotion, which, being an intangible asset of the company, ensures its long-term prosperity. Due to the abundance of brands, the consumer is exposed to many promotional incentives, but he affects the strongest. For the consumer, the value is created by brands that are able to satisfy the main elements: visibility, quality, price, association, brand identity, loyalty, and relationships. The versatility of these elements means that the brand itself must become diverse.

\section{Brand and Brand Image Concept}

Characteristics of the brand image are different in the scientific literature. At one time, the image is understood as part of the process, elsewhere the image is associated with emotions; elsewhere, the image is understood as the information disseminated by the organization. Brands compete with each other, so companies must understand that a good image is the organization's success.

Table 1. Brand image concept 


\begin{tabular}{|c|c|}
\hline Zhang (2015) & $\begin{array}{l}\text { Brand image is the key driver of brand equity, which refers to } \\
\text { consumer's general perception and feeling about a brand and } \\
\text { has an influence on consumer behavior. }\end{array}$ \\
\hline Newman (1957) & Brand image is everything people associate with a brand. \\
\hline Martineau (1959) & $\begin{array}{l}\text { Brand image is in consumer's mind of functional and } \\
\text { psychological attributes. }\end{array}$ \\
\hline Bivainienė, Šliburytė (2008) & $\begin{array}{l}\text { The brand image is related to benefit to consumer, } \\
\text { distinguishing emotions, idionsyncrasies and associations, The } \\
\text { brand image orient to issue how certain group understand the } \\
\text { commodity, brand, policy, company or event country. }\end{array}$ \\
\hline $\begin{array}{l}\text { Lee ,L., J., James, J. D., } \\
\text { Kim, Y. K. (2014) }\end{array}$ & $\begin{array}{l}\text { Brand image forms the basis for making better strategic } \\
\text { marketing decisions about targeting specific market segments } \\
\text { and positioning a product. The phrase, brand image, however, } \\
\text { has been defined and applied in various ways by different } \\
\text { researchers. The variations in definition can be confusing with } \\
\text { regard to brand image measurement and subsequent } \\
\text { assessment of brand equity and brand positioning. }\end{array}$ \\
\hline Aaker (1991) & $\begin{array}{l}\text { Brand image creates value in a variety of ways, helping } \\
\text { consumers to process information, differentiating the brand, } \\
\text { generating reasons to buy, giving positive feelings, and } \\
\text { providing a basis for extensions. }\end{array}$ \\
\hline $\begin{array}{l}\text { Rio,A., B., Vazquez, R. , } \\
\text { Iglesias, R. (2001) }\end{array}$ & $\begin{array}{l}\text { Brand image can be defined as perceptions about a brand as } \\
\text { reflected by the cluster of associations that consumers connect } \\
\text { to the brand name in memory. }\end{array}$ \\
\hline $\begin{array}{l}\text { Bastos, W., Levy, S., J. } \\
(2012)\end{array}$ & $\begin{array}{l}\text { Branding as the naming of a product is essentially a simple } \\
\text { one, the applications of this idea and the thinking about it have } \\
\text { evolved in dramatic ways. To appreciate that evolution } \\
\text { requires awareness of the difference between a sign and a } \\
\text { symbol. }\end{array}$ \\
\hline $\begin{array}{l}\text { Grubor, A. , Milovanov, O. } \\
\text { (2017) }\end{array}$ & $\begin{array}{l}\text { Brand is a unique blend of functional and emotional } \\
\text { characteristic perceived by consumers as an additional value, } \\
\text { unique experience and fulfilled promise]. It has a symbolic } \\
\text { value different from everything that is available in reality, and } \\
\text { ability to represent interests that go beyond the brand itself. } \\
\text { For the company, it is the core strategic resource and most } \\
\text { powerful invaluable asset. }\end{array}$ \\
\hline Pullig, Ch. (2008) & A brand image is strongest when it is highly relevant to your \\
\hline
\end{tabular}




\begin{tabular}{|l|l|}
\hline & $\begin{array}{l}\text { customer. Relevance is determined by what customers want as } \\
\text { they choose their realtor. It may be aggressive marketing, it } \\
\text { may be a solid reputation, or it may be a certain type of } \\
\text { expertise. Market research and understanding your strengths } \\
\text { and the needs of the segment you find most attractive will help } \\
\text { you to determine what type of brand image and specific } \\
\text { associations you want to create. }\end{array}$ \\
\hline Westre, M. (2016) & $\begin{array}{l}\text { Branding is now more than a list of attributes from an } \\
\text { organisation; it is a promise to the customer. Brand marketing } \\
\text { is generally used to promise a unique benefit to customers. }\end{array}$ \\
\hline
\end{tabular}

According to Drūteikienè, Marčinskas (2000), the most convenient way would be to explain the scheme illustrating the organization's image creation (see Figure 1).

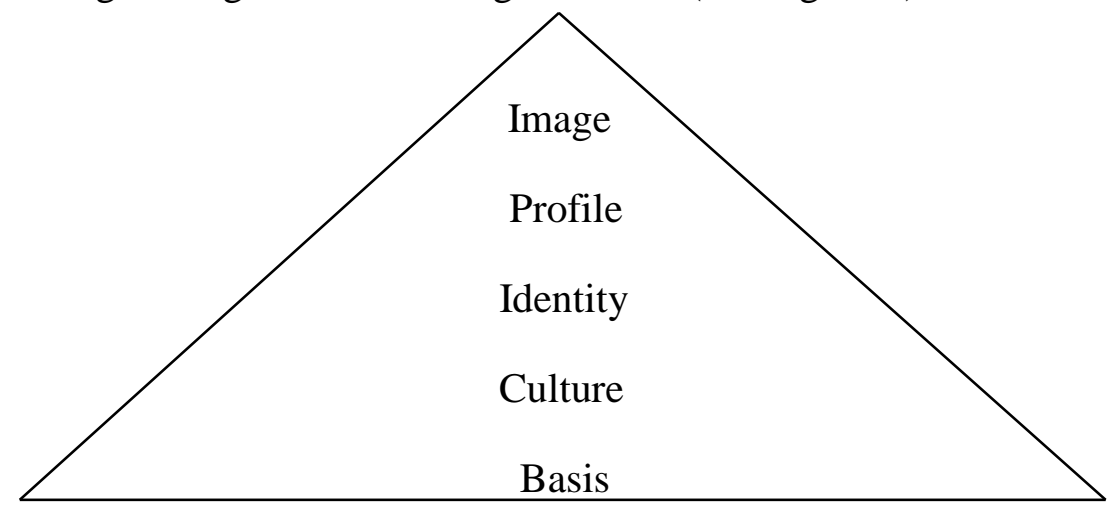

Figure 1. The organization's image creation (Drūteikienè, Marčinskas, 2000)

The culture of the organization's employees recognizes the values and attitudes that manifest themselves in dealing with clients, choosing priorities (mostly unconsciously). Identity is a symbolic expression of the culture. Profile identity elements relevant to public relations. An image of the whole body of impression that a person creates about an organization.

\section{Brand Image Value Models}

Capital market oriented brand value model. Černikovaite (2011) stated that capital market oriented brand value models evaluate y that any one brand is as much as possible worth as much as the consumer is willing to buy. The market value-driven model states that the brand value is calculated on the basis of similar trademarks at market prices. Cost-oriented brand value the measurement model is based on the concept of net asset value, which is often used by corporations in the field of evaluation.

Aaker's brand value model, As stated Černikovaite (2011) Aaker's brand value model is one of the most popular brand value models to highlight the factors that create the product brand value for the consumer. Brand value is understood as a value and liability related to the brand, its name and symbol, which is an integral part or part of the consumer's receipt of the product or 
service. Aaker separates five brand value factors - brand loyalty, brand understanding, perceived quality, brand associations and other related values with the brand.

Brand awareness can be a prerequisite for buying product. The high quality of the product or service encourages consumers to buy, and this means additional profit for the manufacturer. The brand associations are a typical consumer attitude to the brand. Other brand values are the legal and institutional benefits the state can afford to offer a brand and thus protect its value.

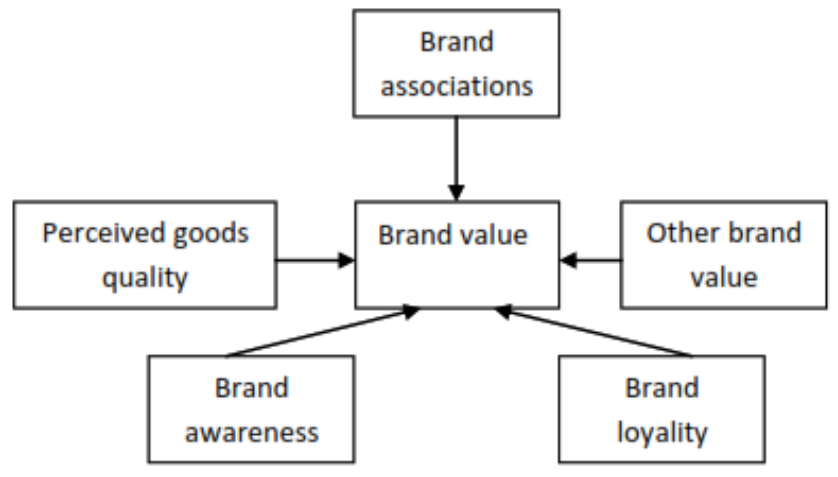

Figure 2. Aaker brand value model (Aaker (1991)

The Inter-brand Brand Assessment Methodology seeks to provide you with a rich and insightful analysis of your brand by clearly showing how your brand contributes to business growth today, along with an action plan for tomorrow's improvement in growth. In order to be included in Best Global Brands, the brand must be truly global, well beyond the geographical and cultural boundaries. It has expanded through established centers of the world economy and entered the main growth markets. From a meaningful point of view, this requires that:

- At least $30 \%$ revenue must be from the trademark location.

- The trademark must be firmly established in Asia, Europe and North America, and has a large geographic scope for emerging markets.

- There must be enough publicly available trademark financial results.

- Profit will be expected to be positive for a long time and profits will exceed the brand's capital costs.

- The trademark must be publicly known and known in all major world economies.

These requirements - for a brand to be global, visible, growing and relatively transparent, based on financial results, it is explained that there are no well-known brands that may appear in the rating.

\section{Brand Value and Benefit}

The most intangible brand element is its brand value, which is reflected in it changes in the brand, user thinking, feelings and actions, as well prices, market share and profitability. The brand value can be measured by examining it awareness, associations, expected quality and consumer loyalty. The brand benefit can be reflected in what consumers feel, feel and behave as regards the brand, as well as the prices, market share and profitability of the brand creates for the company. The brand value is an important intangible asset that is provides financial value to the 
company and has a psychological effect on the consumer. People choose goods that they think are different from others, provided that the difference is meaningful to them. Different can help to create the value of a product by allowing him to manage price supplements.

\section{Table 2. Brand value}

\begin{tabular}{|c|c|}
\hline Author & Definition \\
\hline Maurya, U.K., Mishra, P. (2012) & $\begin{array}{l}\text { Brand values are a subject of notable interest, as shown by } \\
\text { reference to "core brand values" in the academic literature } \\
\text { (e.g. Cook, 1995; Meenaghan, 1995) and the trade (e.g. } \\
\text { Thrift, 1997; Beckett, 1996; Southgate, 1996).Consumers' } \\
\text { decisions are influenced by personal and cultural values. }\end{array}$ \\
\hline Business dictionary (2018) & $\begin{array}{l}\text { Brand value - the premium that accrues to a brand from } \\
\text { customers who are willing to pay extra for it. }\end{array}$ \\
\hline $\begin{array}{l}\text { Margarisová, K., Vokáčová, L. } \\
\text { (2016) }\end{array}$ & $\begin{array}{l}\text { Brand value is a set of assets (and liabilities) associated } \\
\text { with the name and symbol of the brand that increases (or } \\
\text { decreases) the value, which the product or service brings } \\
\text { the company and/ or customer. Each brand asset forming } \\
\text { the brand value creates a product value in many different } \\
\text { ways (e.g. popularity of the known, signal of reliability } \\
\text { and commitment to customers, reduction of marketing } \\
\text { costs, attraction of new customers, a reason to buy, } \\
\text { differentiation/position, process of helping/obtaining } \\
\text { information, creation of positive attitude/feeling, } \\
\text { advantage over the competition, etc.) }\end{array}$ \\
\hline Kaplan, K. (2016) & $\begin{array}{l}\text { Brand is a subjective perception of value based on the sum } \\
\text { of a person's experiences with a product or company that } \\
\text { ultimately influences that person's sentiment and decisions } \\
\text { in the marketplace. Brand is a tool for influencing choice. } \\
\text { Brand is not made of visuals or words alone - it's not a } \\
\text { logo or a slogan. }\end{array}$ \\
\hline $\begin{array}{l}\text { Raggio, R.D., Leone, R., P } \\
\text { (2009) }\end{array}$ & $\begin{array}{l}\text { Brand value must be considered from a firm's perspective, } \\
\text { and generally can be thought of as the sale or replacement } \\
\text { price of a brand. This value will vary depending on the } \\
\text { owner (or potential owner) of the brand, as different } \\
\text { owners may be able to capture more or less of the potential } \\
\text { value of the brand, based on their ability to leverage brand } \\
\text { equity. }\end{array}$ \\
\hline Weng, X.D. (2002) & $\begin{array}{l}\text { The core values of the brand is the main part of brand } \\
\text { equity, it allows consumers to clearly identify and } \\
\text { remember the brand personality point of interest, and even } \\
\text { dominantly force the consumers to fall in love with a }\end{array}$ \\
\hline
\end{tabular}




\begin{tabular}{|l|l|}
\hline Zhang, X.Y. (2011) & brand. \\
\hline & $\begin{array}{l}\text { The brand core values includes the emotional value and } \\
\text { rational value into two parts, in which the emotional values } \\
\text { include historical heritage, personality characteristics, } \\
\text { social characteristics, personal contact degree and } \\
\text { perceived value, rational values include perceived quality } \\
\text { and functional benefits. }\end{array}$ \\
\hline
\end{tabular}

According business encyclopedia (2018) the brand value grows and grows due to customer experience with the brand. The process involves a customer or user's natural relationship with the brand, which occurs according to a predictable model:

- Awareness. A brand is delivered to the target audience, often with advertising, so that it is noticeable.

- Recognition. Customers get to know the brand and recognize it at the store or elsewhere.

- Investigation. Now that they recognize the brand and know what it means, they are trying to do this.

- Preference. When a user has a good brand experience, it becomes a desirable option.

\section{Conclusion}

Brand can be a word or a symbol, a letter, a digit, a design, an emblem, a slogan, a spatial characteristic of the product itself (image, packaging, shape, color), which is marked and helps to distinguish between a person or a product belonging to the company. The brand has its own value. Initially, the value is equal to registration costs, but later, with a reputation, brand value increases. The most expensive world's brand costs billions of euros. Nowadays brand names become so familiar that no one else uses the name of the item, just a sign and everyone understands what is being said, such as Toyota, Pampers, Kempinski, Facebook, and Google. There is several brand value evaluation model like capital market oriented brand value model, Aaker's brand value model, the Inter-brand Brand Assessment Methodology, which help evaluate brand value and benefit.

\section{References}

Aaker, D. A. (1991). Managing Brand Equity. New York: The Free Press.

Bastos, W., and Levy, S. J. (2012). A history of the concept of branding: practice and theory. Journal of Historical Research in Marketing, (4)3, 347-368.

Bivainienè, L., and Šliburytė, L. (2008). The Brand Image As An Element of Brand Equity Socialiniai tyrimai/Social research, (12)2, 22-31.

Business dictionary. (n.d.). What are brand values? definition and meaning. Retrieved 2018, from http://www.businessdictionary.com/definition/brand-values.html

Business encyclopedia (2018). What is Brand Equity?. Retrieved from https://www.shopify.com/ encyclopedia/brand-equity 
Čereška, B. (2004). Reklamos teorija ir praktika. Vilnius.

Černikovaitè, M. (2011). Prekès ženklo vertès matavimo modeliai. Socialiniu mokslu studijos/ Societal studies, (3)3, 967-981.

Interbrand. (n.d.). Best Global Brands. Retrieved 2018, from http://interbrand.com/best-brands/ best-global-brands/methodology/

Kaplan, K. (2016). Brand Is Experience in the Digital Age. Retrieved from https://www.Nngr oup.com/articles/brand-experience-ux/

Lee, L., J., James, J. D., and Kim, Y. K. (2014). A Reconceptualization of Brand Image. International Journal of Business Administration. (5)4, 1-11.

Margarisová, K., and Vokáčová, L. (2016). Regional branding: building brand value. Acta universitatis agriculturae et silviculturae mendelianae brunensis, (64)6, 2059-2066.

Martineau, P. (1959). Sharper focus for the corporate image. Harvard Business Review, (3)1, 4958.

Maurya, U.K., and Mishra, P. (2012). What is a brand? A Perspective on Brand Meaning. European Journal of Business and Management. (4)3, 122-134.

Newman, J. W. (1957). Motivation research and marketing management. Norwood: The Plimpton Press.

Raggio, R. D., and Leone, R. P. (2009). Chasing Brand Value: Fully Leveraging Brand Equity to Maximize Brand Value. Marketing Faculty Publications. http://scholarship.richmond.edu/ marketing-faculty-publications/8

Pullig, Ch. (2008). What is Brand Equity and What Does the Branding Concept Mean to You? Keller Center Research Report, pp. 1-4.

Rio,A., B., Vazquez, R., and Iglesias, R. (2001). The effects of brand associations on consumer response. Journal of consumer marketing, (18)5, 410-425.

Weng, X. D. (2002). Local Brand Strategy. Hangzhou: Zhejiang People's Publishing House.

Westre, M. (2016). Brand associations and the Disney Magic. LSBM working paper series.

Zhang, Y. (2015). The Impact of Brand Image on Consumer Behavior: A Literature Review. Open Journal of Business and Management, 58-62. http://dx.doi.org/10.4236/ojbm.2015 .31006

Zhang, X.Y. (2011) Analysis on the Realization of the Core Values of the Brand. Medium and Small Business Management and Technology, 7, 9-10. 